potential for survival in patients who cannot be maintained on total parenteral nutrition and in particular when treatment is complicated by the development of liver failure. In the long term the goal must be to achieve successful transplantation of the small bowel on its own since only a few patients receiving total parenteral nutrition develop severe liver impairment. As in the early days of all other forms of organ transplantation, there are likely to be more failures than successes. While there is a clear case for developing a clinical small bowel transplant programme in the United Kingdom, the expectations of the profession, the public, and patients at risk must be tempered by a realisation of the difficulties of this most challenging form of organ transplantation.

R F M WOOD Professor of surgery C L INGHAM CLARK

St Bartholomew's Hospital, Wellcome training fellow

London EC1A 7BE
1 Mughal M, Irving M. Home parenteral nutrition in the United Kingdom and Ireland. Lancet 1986;ii:353-7.

2 Lillehei RC, Goott B, Miller FA. The phrsiological response of the small bowel of the dog to ischaemia including prolonged in vitro preservation of the bowel with successful replacement and survival. Ann Surg 1959;150:5+3-60.

3 Grant D, Hurlbut D, Zhong R, Wang P, Chen H, Garcia B, et al. Intestinal permeability and bacterial translocation following small bowel transplantation in the rat. Transplantation 1991;52:221-4.

4 Smith GJ, Ingham Clark C, Crane P, Lear P, Wood RFM, Fabre JW. Ex vivo perfusion of intestinal allografts with anti- $T$ cell monoclonal antibody/ricin $A$ chain conjugates for the suppression of graft-versus-host disease. Transplantation 1992;53:717-22.
5 Ingham Clark CL, Price BA, Crane PW, Lear PA, Wood RFM. Persistence of allogeneic cells in graft versus host tissues after small bowel transplantation. Br f Surg 1992;79:424-6.

6 Iwaki Y, Starzl TE, Yagihashi A, Taniwaki S, Abu-Elmagd K, Tzakis A, et al. Replacement of dono lymphoid tissue in small bowel transplants. Lancet 1991;337:818-9.

Wood RFM, Lear PA, Ingham Clark CL. First international symposium on small bowel transplantation. Transplant Proc 1990;22:2423-503.

8 Grant D, Wall W, Mimeault R, Zhong R, Ghent C, Garcia B, et al. Successful small bowel/liver transplantation. Lancet 1990;335:181-4.

9 Calne RY, Sells RA, Pena JR, Davis DR, Millard PR, Herbertson BM, et al. Induction of immunological tolerance by porcine liver transplantation. Nature 1969;223:472-6.

\title{
ISIS 3: the last word on thrombolysis?
}

\author{
Streptokinase and aspirin win the vascular sweepstakes
}

The debate over the best thrombolytic agent has engendered two of the largest clinical trials ever undertaken, the GISSI-2 (Gruppo Italiano per 1o Studio della Sopravvivenza nell' Infarcto Miocardico) study with its international extension ${ }^{12}$ and the recently published ISIS-3 trial (third international study of infarct survival). ${ }^{3}$ These studies, of 20891 and 41299 patients respectively, have resolved most of the questions regarding the choice of thrombolytic agents and the role of heparin.

Before them, trials had shown that streptokinase,${ }^{+5}$ tissue plasminogen activator, ${ }^{6}$ and anistreplase ${ }^{7}$ all reduced deaths from acute myocardial infarction, but, without comparative studies, deciding which was the best thrombolytic drug had been impossible. An overview of angiographic studies had shown that tissue plasminogen activator (both single chain alteplase and double chain duteplase) and probably antistreplase achieved better early coronary patency than streptokinase, although there was nothing to choose between them by 24 hours. ${ }^{3}$ Controversy raged over whether the superior early coronary patency achieved by tissue plasminogen activator would result in improved survival. Further uncertainty surrounded the role of heparin once it was established that antithrombotic treatment with aspirin greatly enhanced the benefit of treatment with streptokinase. ${ }^{2}$

In ISIS-3 patients were recruited up to 24 hours (median four hours) after the onset of symptoms of a myocardial infarction. Patients were randomised to receive fibrinolytic treatment with streptokinase, tissue plasminogen activator (duteplase), or anistreplase plus antithrombotic treatment with either aspirin and heparin or aspirin alone. The heparin regimen was 12500 units twice daily by subcutaneous injection. The report of the trial described the effects of treatment on various hospital events as well as total deaths and deaths due to vascular causes at 35 days, analysed according to intention to treat.

Comparison of aspirin and heparin with aspirin alone (with all patients receiving thrombolytic agents as well) showed that more aggressive antithrombotic treatment was associated with an increased risk of bleeds requiring transfusion and other major non-cerebral bleeds $(1.0 \% v 0.8 \% ; 2 / 1000)$ and of definite or probable cerebral haemorrhage $(0.6 \% v 0.4 \%$; $2 / 1000)$. Neither the total number of strokes nor the number of fatal and disabling strokes was significantly increased in the group treated with heparin. The incidence of reinfarction was non-significantly lower in the group treated with heparin. This held true when data from ISIS-3 and GISSI-2 were combined. Deaths fell slightly during scheduled heparin treatment in both ISIS-3 and GISSI-2; a slight excess of deaths after the end of treatment, however, meant no overall reduction in mortality at 35 days or six months in the group treated with heparin.

Direct comparison of streptokinase and anistreplase in ISIS-3 was based on 13780 and 13773 patients respectively. Treatment with anistreplase resulted in significantly more allergic reactions, non-cerebral haemorrhage, cerebral haemorrhage, and disabling or fatal stroke. There was no difference in the incidence of reinfarction or in mortality at 35 days or six months. In the same study the comparison of streptokinase and tissue plasminogen activator (duteplase) was based on 13780 and 13746 patients respectively. Allergic reactions and hypotension were less common after tissue plasminogen activator. The incidence of disabling or fatal strokes was higher after tissue plasminogen activator $(1.39 \% v$ $1 \cdot 04 \% ; 4 / 1000)$ while the reinfarction rate was lower $(2 \cdot 93 \%$ v $3.47 \% ; 5 / 1000)$. There was no significant difference in overall mortality at 35 days. Pooled results from ISIS-3, GISSI-2, and other small trials indicate an identical short term mortality after streptokinase and tissue plasminogen activator.

The results of ISIS-3 and GISSI- 2 seem to vindicate the use of the cheaper drug, streptokinase. It works as well as tissue plasminogen activator and anistreplase but carries less risk of stroke.

Similarly, heparin seems to confer no extra advantage in patients receiving an adequate daily dose $(160-325 \mathrm{mg})$ of aspirin. Some have argued, however, that the results are 
irrelevant to the current use of tissue plasminogen activator as duteplase is no longer marketed and the heparin given was "too little, too late." The question of the preparation of tissue plasminogen activator is answered by the report on ISIS-3, which showed in a meta-analysis of studies of patency that alteplase and duteplase produce virtually identical effects at 90 minutes.

Relevant to the doubts about heparin is a recent study of the effect of intravenous heparin started immediately after tissue plasminogen activator in patients receiving $250-300 \mathrm{mg}$ aspirin daily ${ }^{8}$ It found a moderate but significant increase in coronary patency $(84 \% v 75 \%)$ in the heparin treated group. Patients received heparin subcutaneously at the end of the infusion of tissue plasminogen activator (ISIS-3) and after 12 hours (GISSI-2). Whether earlier, more aggressive use of heparin by bolus injection and infusion would reduce the risk of reocclusion in patients treated with tissue plasminogen activator, thereby improving survival, is currently being tested in the global utilisation study of streptokinase and tissue plasminogen activator for occluded coronary arteries (GUSTO). The authors of the report on ISIS-3 suggest, however, that if the heparin regimen was indeed inadequate to prevent reocclusion then more reinfarctions would have occurred in patients treated with tissue plasminogen activator, whereas the opposite happened. Furthermore, a more aggressive regimen may have exacerbated the existing excess of stroke in the patients treated with tissue plasminogen activator, offsetting any gains from improved coronary patency.

Do anistreplase and alteplase have any role in current treatment? The advantage of anistreplase is that it may be given by bolus injection, which makes it more suitable for rapid administration before admission to hospital. A limited but definite role for alteplase exists in the management of reinfarction in patients previously treated with streptokinase. Studies of antibodies to streptokinase after myocardial infarction have shown that titres sufficient to inactivate the conventional 1.5 million unit dose may persist for at least a year. ${ }^{910}$ The risks of inefficacy and allergic reaction suggest that alteplase should be used for reinfarction unless techniques for rapid analysis of antibodies to streptokinase become available.

Thus the outcomes of ISIS-3 and GISSI- 2 have resulted in a policy of no change and a sigh of relief from most British doctors and general managers. Aspirin and streptokinase remain the treatment of choice in myocardial infarction; there seems little justification for adding heparin. The emphasis should now be on audit to ensure that all potentially suitable patients, including elderly patients, receive aspirin and streptokinase and that delays to treatment in hospital are kept to a minimum.

STUART M COBBE

Walton Professor of Medical Cardiology

Royal Infirmary,

Glasgow G31 2ER

1 Gruppo italiano per lo Studio Della Sopravvivenza Nell'Infarcto Miocardico. GISSI-2: a factorial randomised trial of alteplase versus streptokinase and heparin versus no heparin among 12490 patients with acute myocardial infarction. Lancet 1990;336:65-71.

2 The International Study Group. In-hospital mortality and clinical course of 20,891 patients with suspected acute myocardial infarction randomised between alteplase and streptokinase with or without heparin. Lancet 1990; 336:71-5.

3 Third International Study of Infarct Survival Collaborative Group. ISIS-3: a randomised comparison of streptokinase vs tissue plasminogen activator vs anistreplase and of aspirin plus heparin vs aspirin alone among 41,299 cases of suspected acute myocardial infarction. Lancet 1992;339:753-70

4 Gruppo Italiano per to Studio Della Streptochinasi Nell'Infarco Miocardico. Effectiveness of intravenous thrombolytic treatment in acute myocardial infarction. Lancet 1986;i:397-402.

5 ISIS-2 (Second International Study of Infarct Survival Collaborative Group). Randomised trial of intravenous streptokinase, oral aspirin, both or neither among 17,187 cases of suspected acute myocardial infarction. Lancet 1988;ii:349-60.

6 Wilcox RG, Olsson CG, Skene AM, von der Lippe G, Jensen G, Hampton JR. Trial of tissue plasminogen activator for mortality reduction in acute myocardial infarction. AngloScandinavian study of early thrombolysis (ASSET). Lancet 1988; ii:525-30

7 AIMS Trial Study Group. Effect of intravenous APSAC on mortality after acute myocardial infarction: preliminary report of a placebo-controlled clinical trial. Lancet 1988; i:545-9.

8 de Bono DP, Simoons ML, Tijsen J, Arnold AER, Betriu A, Burgersdijk C, et al. Effect of early intravenous heparin on coronary patency, infarct size and bleeding complications after alteplase thrombolysis: results of a randomized double blind European Cooperative Study Group trial. thrombolysis: results of a rand

9 Lynch M, Littler WA, Pentecost BL, Stockley RA. The immuglobulin response to intravenous streptokinase in acute myocardial infarction. Br Heart $\mathcal{f}$ 1991;66:139-42.

10 Jalihal S, Morris GK. Antistreptokinase titres after intravenous streptokinase. Lancet 1990;335: 184-5.

\section{Audit in general practice}

\section{Improves care}

Medical audit advisory groups were established just over a year ago, and all general practitioners are now meant to be taking part in audit. Although it is too early to assess the value of these groups, questions have already been raised about their role in ensuring quality. The cost in time and money of audit without evidence that it is the most efficient method of effecting change has been sharply criticised. ${ }^{1}$ Experience from the first year shows that audit presently being undertaken in practices is too often limited to collecting data without completing the audit cycle. ${ }^{2}$ In their attempts to promote audit members of medical audit advisory groups have encountered varying degrees of interest, ranging from enthusiasm to apathy and even hostility. These groups would therefore welcome guidance on how audit can be used to improve patients' care.

This week the $B M \mathcal{F}$ publishes two papers that throw some light on the effectiveness of medical audit (p 1480), ${ }^{3}$ (p 1484). ${ }^{4}$ The north of England study of standards and performance in general practice, based in 62 training practices, was designed to evaluate the effects of setting clinical standards. Though the overall design of the study was simple, it was large and took 10 years to complete. Preliminary information about process was collected by examining the records of children who had one of five selected conditions: acute cough, acute vomiting, bedwetting, itchy rash, or recurrent wheezy chest. A combination of interviews and questionnaires completed by parents were used to collect information about outcome.

Subsequently 84 trainers from these 62 practices were allocated to 10 groups, each of which set a standard for one of the study conditions. They also participated in four other strategies, one for each of the study conditions for which they had not set a standard. Each combination of condition and strategy was randomised to different groups, and information about process and outcome was collected for up to two years. Standard setting was shown to improve care and, for one condition (recurrent wheezy chest), outcome. Receiving either a standard or information about group performance was not followed by improvements.

Although this is an important study and is likely to have a substantial influence on the development of audit in the 